\title{
3. Acting for cities and towns? The perpetual reinvention of categories and tools of national urban policies in France
}

\author{
Christophe Demazière and Olivier Sykes
}

\section{INTRODUCTION}

\subsection{Current Local Government System and Recent Changes Impacting on Urban Policies}

France is a unitary state with decentralisation that began in the 1980s and continuously deepened in the following decades. The three levels of local government (regions, departments and municipalities) are freely managed by elected councils, using their own resources and allocations from the state. All layers of subnational governments are autonomous and none exercises control over another.

The fragmentation of municipalities is extreme in France. There are 35000 communes, that is, 40 per cent of all municipalities in the European Union for only 13 per cent of the European population. Due to high financial autonomy many municipalities used to compete for economic and residential development, including within the same conurbation. This is why national governments have favoured the creation of établissements publics de coopération intercommunale (EPCIs - public intercommunal cooperation institutions) to which municipalities voluntarily transfer resources such as the tax paid by companies, and strategic competences such as economic development, culture and housing. These EPCIs are eligible for major government subsidies, which has encouraged municipalities to engage in them. Although the elected members of these structures are elected at the municipal level and not directly to the EPCIs, the latter must be considered a key (and a fourth) level of French territorial authority. Acknowledging the very small size of the core municipality, many mayors of large cities created an EPCI with their suburban 
colleagues and were able to launch very ambitious regeneration, public transport or cultural projects (Demazière and Sykes 2020).

Since 2010, France has witnessed major territorial reform and a redefinition of the levels of subnational government and their competences. This has involved an enlargement of the perimeters and capacities to act of regions, and a reinforcement of the groupings of municipalities mentioned above. In rural areas, the population of an EPCI should now be at least 15000 inhabitants, which has caused many mergers. In large cities, in response to the growing power of inter-municipal associations, a new category of EPCIs was created: the 'métropoles' (Demazière and Sykes 2020). This institutional reform was put forward by mayors of large cities who, in the case of France, used to be also members of the parliament and of national government for a long period. ${ }^{1}$ But it also shows a clear evolution in urban policy in the context of austerity for the national public finances: the state leaves 'métropoles' to deal with the current challenges of urban development.

Between 2010 and 2016, two successive reforms of local authorities were carried out, first by a right-wing government and then by a socialist government. The reform was prefigured by an official report to President Nicolas Sarkozy, which proposed the reduction of the number of regions through mergers, comprehensive national coverage of intercommunal cooperation, and the setting of a population threshold for any EPCI. At the time, not all these measures were implemented, many parliamentarians of all sides being hostile to them. The law made possible the creation of a métropole for any municipal grouping of more than 500000 inhabitants. However, initially, only in Nice was a métropole created.

In 2015, under President Hollande, the Loi portant nouvelle organisation territoriale de la République (NOTRe - law on the new organisation of the territory of the Republic) clarified the responsibilities of the different levels of territorial authorities. The number of regions was reduced from 22 to 13 with, in addition, 5 regions overseas. The justification put forward by the government for this reform was the need to establish regions of 'European size' - that is, more comparable to those in other European countries. However, public management seems a more plausible explanation. While the national government had continuously supported the growth of local spending by increasing its grants, it changed tack in 2015, reducing subsidies to local governments for three years, and making a return to a stable level of support contingent on the efforts of local governments to limit their expenditure.

The creation of metropolitan government shows a continuity between governments of the right and left. In 2010, a right-wing government decided that Paris - the biggest municipality in France - should unite with others while gaining the special status of 'métropole du Grand Paris'. This controversial project was continued by the socialist government after 2012. The Greater 
Paris metropolis was legally created in 2016, grouping Paris with 130 municipalities. In 2014, the Loi de modernisation de l'action publique territoriale et d'affirmation des métropoles (MAPTAM - law for the modernisation of territorial public action and affirmation of the metropolises) designated eight 'métropoles' each having more than 400000 inhabitants in a wider urban region of more than 650000 inhabitants. $^{2}$ The president of the métropole is elected by the metropolitan councillors, who are firstly local councillors of the constituent municipalities. As mentioned above, Nice is already such a grouping and Greater Paris has its own bespoke arrangements. In spite of the strong opposition from the mayors of Provence, the métropole of Aix-Marseille Provence was created at the scale of the entire functional urban region. In Lyon, the most complete form of metropolitan governance in France has taken shape, as the métropole has absorbed the policy fields of the department du Rhône within its boundaries and in 2020 the metropolitan councillors have been elected directly by the population for the first time.

\subsection{Current Challenges of Urban Areas}

France has 67 million inhabitants within a territory covering $550000 \mathrm{~km}^{2}$, and its population density is quite low (119 hab./sq. km in 2018). Urbanisation took place later than in other Western European countries. It was mainly during the 1950s and 1960s, when Fordist industries attracted rural populations, that large cities but also small towns underwent a process of growth. Urban development then often took the form of large-scale social housing units and industrial parks (Demazière 2017).

Regarding the recent challenges to be addressed by urban areas, there is no official document from the government. In the 1990s, there was an attempt to develop a schéma national d'aménagement du territoire (national land use plan), but the exercise proved to be too complex and it was replaced by sectoral blueprints, which had little influence. To account for the present situation of urban areas, we refer here to the Observatoire des territoires (Territorial Observatory), an official body that has been set up by the ministry in charge of regional planning so as to inform public decision-makers. Its role has been to provide evidence in the face of growing political debates that put forward a binary view of spatial disparities, a 'territorial divide' setting 'winners' against 'losers' and 'centres' against 'peripheries'.

The report of the Observatoire des territoires (2017) reveals two superimposed geographies that help to make sense of the challenges faced by urban areas in France. First, four groups of regions are experiencing very different evolutions in population and employment. Due to their demographic and economic dynamism, Atlantic and Mediterranean coastal areas, along with the Rhone Valley, stand out from the north-eastern quarter of France affected by 
deindustrialisation, and from a central region with sluggish demographics due to a very noticeable ageing of its population. The capital region, île-de-France, concentrates 21 per cent of the country's jobs and 18 per cent of its population, and produces around 30 per cent of the country's GDP. It is also the French region where population and employment have increased most since 1999.

Second, it is possible to distinguish major types of areas (metropolises, medium-sized towns, and periurban and rural areas) with differing dynamics and problems. Overall, large cities have benefited more from recent economic changes than medium-sized towns and rural areas, and an increasing polarisation of the largest urban areas can be observed in all regions, resulting in the expansion of periurban areas. In contrast, various thinly populated areas have been experiencing population and employment losses for several decades. But these major variances in overall dynamism mask a huge heterogeneity at the local level.

Large cities (taken here to mean urban areas with over 200000 inhabitants, apart from Paris) accommodate 38 per cent of the country's population and 39 per cent of its jobs, and account for an even greater part of its demographic and economic growth over recent years (Observatoire des territoires 2017). Among these large agglomerations, those in the west and south (Nantes, Bordeaux, Toulouse etc.) recorded the most growth. In contrast, the large agglomerations in the east and north recorded growth levels lower than the national average, although still higher than the pace of growth in their respective regions. Fast-growing agglomerations face serious problems of congestion and are also extremely unequal areas: the ratio between the incomes of the wealthiest 10 per cent and the poorest 10 per cent households varies from 3.9 to 4.1 in most metropolises, as against 3.5 for France as a whole. They therefore face particularly significant social and territorial cohesion issues.

Small towns (urban areas with 5000 to 20000 inhabitants) and medium-sized towns (having between 20000 and 100000 inhabitants) heavily depend on the dynamism of the region to which they belong and/or to their proximity to a metropolitan area (Demazière 2017). Some are dynamic, but representations in the French media generally stress the problems of small urban centres facing job losses and periurbanisation of the population. Such towns experience the cumulative effects of decline: fewer inhabitants and jobs, vacant accommodation, and closing of services (Berroir et al. 2019). As consumers tend to prefer shopping malls in peripheral areas over their city-centre counterparts, the core municipalities of small towns record the country's highest vacancy rate for businesses (IGF-CGEDD 2016).

The devitalisation of urban centres outside metropolitan regions is increasingly seen as being a major challenge to the country's territorial cohesion. In contrast, the economic and demographic dynamism displayed by large French cities has nurtured the idea of a territorial divide between metropolises, 
bastions of the elite that bear up well, and forgotten peripheral areas that are seen as abandoned (Guilluy 2014). This view is obviously too schematic: it is quite simply impossible to group all territories classified as 'metropolises', 'small towns' or 'isolated rural areas' into the same categories, as there is far too much variation in their development trajectories and in their inhabitants' profiles (Berroir et al. 2019). Nevertheless, the simplicity of the image of a territorial divide, the rise of the extreme right vote in 'peripheral areas' through the last two decades and the recent 'Yellow Vests' movement have extended the list of places national urban policies might target, at the risk of reducing their visibility and/or efficiency.

\section{EVOLUTION OF NATIONAL URBAN POLICIES}

To understand what has changed in the national urban policies in France over recent decades, we need to go back to the 1980s when a socialist government (the first ever during the Fifth Republic) both launched decentralisation and developed a policy targeting disadvantaged neighbourhoods. Decentralisation was continued through the following decades. It forced the state apparatus to modify its role, being much less present and active in urban areas, but rather 'steering at distance' (Epstein 2015) the initiatives of local governments. On the other hand, 'a solution to the problems of disadvantaged neighbourhoods has eluded policy makers (...), primarily as a result of a failure to develop a coherent multi-faceted response to this multi-faceted problem' (Hall and Hickman 2002, p. 691).

\subsection{Period 1981-2002: Most Difficult Places First}

Central and local government's policy towards urban areas can be divided into two key areas: policies that seek to address conurbations and urban areas as a whole, and those which address deprived neighbourhoods within cities (Couch et al. 2011). It is the latter group of policies that collectively constitute France's politique de la ville (city policy), but in order to gain a full appreciation of the context within which policy for urban areas sits, it is useful to consider the evolution of wider regional policy approaches in France.

\subsubsection{National regional policy and policy concerned with national urban structure}

In France, a spatially informed national regional policy approach known as aménagement du territoire (AT) was established in the 1960s, reflecting a concern to secure a better balance of development between the Paris region and the rest of France. The creation of the Délégation à l'Aménagement $d u$ Territoire et à l'Action Régionale (DATAR) and the designation of 12 major 
urban centres outside the Paris region as 'métropoles d'équilibre' (balancing metropolises) were emblematic of this policy (Demazière 2006). From the mid-1970s until the 1990s, economic crisis and restructuring, unemployment, state reform and European integration changed the context for the pursuit of AT. The goal was no longer to just redistribute growth away from Paris, but to address problems like unemployment caused by deindustrialisation and to attract inward investment. Since the 1990s, France's approach to regional policy increasingly shifted to an 'endogenous' model, the goal being to foster the development of regions by encouraging them to draw on their attributes, with the state playing a supportive role through the use of territorial 'contracts'. The latter were typically signed between the state and cities - for example, a contrat d'agglomération (conurbation contract) could be used to take a strategic and long-term view of a conurbation's development, and within these a contrat de ville (town contract) could address the development and social and territorial cohesion needs of a particular neighbourhood (Couch et al. 2011).

\subsubsection{Disadvantaged neighbourhoods: the invention of a partnership policy à la française}

In the early $1980 \mathrm{~s}$, the state set up the politique de la ville, which literally translates as 'city policy' but in fact is more specifically targeted at 'disadvantaged' neighbourhoods. It was around this time that social problems began to become more evident in the large suburban housing estates of the 'banlieues' (suburbs). These had been constructed between the 1950s and 1970s to meet the housing needs of a nation experiencing rapid population growth, migration from rural to urban areas, and industrialisation. Many of the apartment buildings in such areas had deteriorated over time and this, combined with a frequent lack of facilities and good transport links to employment centres, led many better-off residents to move out to be closer to city centres, or to seek accommodation in houses rather than flats (Couch et al. 2011). The end of the 30-year period of post-WW2 economic growth also meant that many of the remaining residents faced problems such as unemployment, poor access to services and poor estate management. These issues often affected many of the immigrant families who had come to France to sustain the country's economic growth and modernisation but now faced challenging economic conditions and reduced employment opportunities.

In July 1981, disaffected youths, the majority of whom were unemployed and of immigrant heritage, confronted the forces of law and order in the suburbs of Lyon. In response the socialist government launched a large-scale 'policy for the city' aimed at ending social exclusion among such groups and in such areas. From 1982 until 1988, a programme called Développement social des quartiers (DSQ) (Social Development of Neighbourhoods) was 
funded by central government. It focused on issues of education and social, economic and public order problems. Reflecting the increased decentralisation of responsibilities from the central state to communes, responsibility for running the DSQ programme was handed to local mayors.

In 1988 the politique de la ville became more institutionalised. A Délégation interministérielle à la ville (DIV - inter-ministerial delegation for cities) was established to mobilise the various city policy makers (central government staff, local governments, non-profit organisations). Local authorities and the state worked together to implement a pluriannual programme of integrated urban development, and 214 contrats de ville (CDV) were put in place in the 1988-1996 period. CDVs pursued a more global 'conurbation' approach than DSQ, looking at wider economic and social issues and how disadvantaged neighbourhoods could be improved. They were integrated into the Contrats de plan Etat-Région. These were 'conceived as a vehicle for reconciling the imperative to address social exclusion in an integrated manner with the fragmentation of local governance that was reinforced by the decentralisation programme' (Hall and Hickman 2002, p. 692).

In 1990, in the wake of more serious urban riots in Lyon and Mantes-la-Jolie, the government established a Ministère de la ville (Ministry for Urban Affairs), and in 1991 the Loi d'orientation pour la ville (framework law for cities) was passed. This sought to secure a greater social mix of housing tenures between the communes in urban areas by obliging agglomerations with more than 200000 inhabitants to provide at least 20 per cent social housing. By the mid-1990s, however, there was a feeling that the principles intended to inform contrats de ville were not always being applied in practice, and that, in particular, public interventions continued to be along sectoral lines rather than adopting an integrated approach to neighbourhoods (Lelévrier 1999). The Pacte de relance pour la ville (PRV), launched in response in 1996 by the right-of-centre Juppé government, is seen by Hall and Hickman (2002, p. 693) as representing a return to the emphasis on 'spatial positive discrimination' that had characterised the earlier DSQ. The new initiative designated 751 so-called zones urbaines sensibles (ZUSs - vulnerable urban areas), which were facing problems such as poor housing and high unemployment. The introduction of ZUSs was accompanied by the establishment within these areas of zones franches urbaines (ZFUs - economic opportunity zones). For Hall and Hickman (2002, p. 693) the ZFUs signal a 'brief flirtation on the part of the French authorities with "Anglo-Saxon" style economic regeneration, based on fiscal deregulation, in the form of enterprise zones'. 


\subsection{Period 2002-2012: Promoting Economic Competitiveness and Implementing Urban Renewal}

In the first decade of the 21st century, like several other European countries, France experienced a shift from a Keynesian welfare state to a Schumpeterian workfare state (Jessop 1993). Here the state is no longer concerned primarily with the goal of full employment, but with the competitiveness of the national economy - which may eventually lead to a high level of employment. In France, the politique de la ville was transformed by 'roll back policies' (Tickell and Peck 2003) designed to undermine the institutions and policies of the post-war welfare state. On the other hand, in the name of aménagement $d u$ territoire, a 'roll-out neoliberalism' developed that sought to foster economic competitiveness (Demazière 2006).

\subsubsection{Aménagement du territoire - from balancing growth to promoting competitiveness}

In 2004, a call for projects - entitled 'Pour un rayonnement européen des métropoles françaises - Appel à coopération métropolitaine' (To develop the European influence of French metropolises - Call for metropolitan cooperation) - was launched by DATAR aimed at the large European-scale urban regions in France (except the Paris region). The aim was not to organise specifically cooperation between a large city and its surrounding suburban groupings of municipalities. Rather, by suggesting the formation of alliances between areas in a single urban region or in different urban areas, it opened the way for cooperation between actors interested in the development of large cities rather than in forming or reinforcing territorial cohesion. The call for projects had a strong economic rationale and was based on two observations. First, it stressed the essential role of cities in the economic development of France. Second, it showed the limited economic weight of the French cities compared to other European countries. In general, French cities with more than 200000 inhabitants are under-developed regarding financial services, have a weak scientific influence and a modest activity in terms of international trade fairs and congresses (Rozenblat and Cicille 2003).

The call for applications focused policies on a new scale of public action: the 'métropole', defined as areas with a minimum of 500000 inhabitants which included at least one urban district with over 200000 inhabitants and several medium-sized towns. This definition allowed about 42 urban areas to be identified for potential cooperation.

The call for metropolitan cooperation was fairly successful. DATAR received 20 applications (which involved 40 urban areas) and it selected 15. Local authorities were supposed to develop a metropolitan project, and later on a 'metropolitan contract' would be signed for the period 2007-2013. However, 
the policy had a short life. The government announced soon after that it would not sign any contract, due to a lack of financial resources. The failure of this initiative 'confirmed that the State no longer has the means of conducting a metropolitan policy, and it is therefore up to the areas themselves, towns, urban districts, and often départements, as well as their stakeholders (...) to take it up' (Vanier 2007, p. 79).

\subsubsection{New aims and new methods for la politique de la ville}

In 2002, following the election of a centre-right government, there was a feeling that the approaches of the previous decades to try and improve the urban environment had shown their limitations. In an influential report to the government, Jean-Pierre Sueur (1998), then deputy-mayor of Orléans, was critical of the way in which the contrats de villes had been implemented. He argued that their content was not fully comprehensive, objectives were vague, procedures were complex and evaluation was inadequate.

In 2003 a Loi sur la rénovation urbaine (law on urban renovation) launched a five-year programme which developed a physical approach to urban regeneration. The 'Programme national pour la rénovation urbaine' (PNRU - National urban renewal programme) promoted work on public spaces and services and significant interventions on the housing front in 150 neighbourhoods, with the demolition and reconstruction of 200000 dwellings and the rehabilitation of a further 200000 . The DIV has lost its ability to coordinate the urban policy, as an Agence nationale pour la renovation urbaine (ANRU - National Urban Renewal Agency) was created with responsibility for overseeing the PNRU. The programme had the goal of renewing 530 neighbourhoods with almost 4 million inhabitants by 2013 through an investment of 40 billion euros, with the oversight of the ANRU being intended to remove administrative obstacles. This approach marked a clear shift of the politique de la ville towards a physical approach to regeneration. It also meant a shift from a partnership with local governments to a state-led approach. In brief, the politique de la ville 'abandoned the bottom-up and cross-sector approach that had characterised it, prioritising instead the implementation of a demolitionreconstruction program, the objectives and content of which had been decided on at the national level, and the local version of which was carried out through calls for projects from cities' (Epstein 2015, p. 468).

However, a turn away from the more social focus of previous programmes has been blamed in some quarters for the wave of riots which took place in November 2005. As a response, a National Agency for Social Cohesion and Equal Opportunities was established. In 2007, the contrats de villes (CDV) were replaced by contrats urbains de cohésion sociale (CUCs - urban contracts for social cohesion). In a search for efficiency, these new contracts were signed for a shorter period of three years instead of the six-year term of 
the CDVs, and they had multi-year action plans, unlike the CDVs which had one-year financial programmes.

During the 2007 presidential campaign, candidate Nicolas Sarkozy promised a 'Marshall plan' for the suburbs. After his election, he nominated as Secretary of State responsible for City Policy, Fadela Amara, who was a civil society activist. Amara drew the broad outlines of the ambitious plan Espoirs Banlieues (Hope for the suburbs) which was to focus on a hundred neighbourhoods with social insertion through work, the fight against school failure, and urban regeneration as priorities. The context of economic crisis following 2008 was not propitious for the funding of this programme. In December 2011, a few months before presidential elections, the successor of Amara, Maurice Leroy, explained that it was no longer the moment for expensive large-scale plans 'because nobody believes' in them and they are 'now unrealistic in a financial context which forces us to be very vigilant in budgetary matters'.

In sum, the politique de la ville has focused on deprived neighbourhoods for decades, but it has kept swinging from interventions designed to address social issues to a physical 'bricks and mortar' approach. This evolvement echoes the debate surrounding the relative success or failure of such urban policy. Billions of francs were spent on the regeneration of housing estates and extra resources for schools and youth schemes in the suburbs, but such actions ultimately proved ineffectual (Epstein 2016). Reflecting on the PNRU, Lévy-Vroelant (2007) asks: 'what is the added value of the upgrading of the built environment when the underlying problems are social and economic relating to lack of schooling, low qualifications and unemployment?' (p. 115). This programme promotes urban renewal with the objective, in the long term, of eradicating social segregation; however, there is no mechanical relationship between the improvement of the living environment and social diversification. Actually, the inequalities between the inhabitants of the targeted districts and those of the agglomerations on which they depend have widened even more, particularly in terms of jobs, income and social mix (Epstein 2015).

\subsection{Period 2012-2017: In Search of 'Égalité des Territoires' in Times of Austerity}

The 'crise des banlieues' (crisis in the suburbs) continues to be an important political issue in France and one which attracts much attention from the media (Epstein 2016). To a certain extent, la politique de la ville has taken the form of successive recovery plans, their contents and their instruments taking quite similar forms. Often preceded by spectacular riots, each new cycle is announced with great fanfare and very ambitious objectives, yet these policies never seem to reach their goals. Maybe for this reason, other urban areas have 
emerged in the last decade as being 'in crisis' and as meriting a national policy, namely small and medium-sized towns.

\subsubsection{A plan for all poor urban areas?}

After 30 years of politique de la ville that remains both centralised and highly territorialised, with a strong predominance given to place, the expected socioeconomic changes do not seem to have occurred. Faced with this observation, after 2012 the left-wing government under François Hollande wanted to overhaul the zoning criteria and refocus actions on the districts most in difficulty.

The measures contained in the Loi de programmation pour la ville et la cohésion urbaine (programming law for the city and urban cohesion) of February 2014 revolved around four axes. The first was the revision of priorities, with the main objective being to target state spending on a more limited number of districts (reduced from 2500 to 1000). The second aim was to mobilise sectoral policies and to reaffirm the need for territorial solidarity. Henceforth 1294 districts were to be covered by a single contrat de ville (CDV) (compared with 2493 CUCs previously), to be signed between the state and all local actors (local authorities, employment agency, family allowance fund, etc.) for the 2015-2020 period. The CDVs integrate the social and the urban, by creating a unique and 'global' intervention approach on an inter-municipal scale. They are very similar in their structure and their aims to those signed in the 1990s (Epstein 2016). The third aim was to complete the urban renewal programme and even to launch a new generation of operations. Quite innovatively, the last commitment aimed at involving residents in decisions and projects, including a co-elaboration of CDVs. To this end, citizens' councils were set up in each neighbourhood, so as to give inhabitants a real power to act. This meant a 'significant evolution of public discourse on working-class neighbourhoods and their inhabitants, who are no longer presented as the cause of problems but as actors in their resolution and in the implementation of (light) participatory mechanisms' (Epstein 2016, p. 4).

The zoning reform was made by identifying priority neighbourhoods on the basis of a single criterion: the urban concentration of population whose resources are less than 60 per cent of the national median income, that is, the poverty line. Income was seen as a simple (thus easily understandable) criterion capable of capturing relatively well all the demographic and socioeconomic characteristics used to geographically define the previous priority areas: unemployment, large families, structure of the housing stock and so on. However, zoning implies that financial resources are mostly oriented towards specific territories and objectives (place-based policies). In France, there are difficulties in developing people-based policies and in integrating this empowerment, which is at the heart of urban policies in other countries (Donzelot 2003). 
Due to the redefinition of eligibility criteria, small and medium-sized towns - that is, urban units centred on central municipalities of between 20000 and 100000 residents - were suddenly brought within the new geography of the politique de la ville. Indeed, while metropolitan city centres have benefited since the 1980s from revitalisation policies and growth dynamics, many of the central districts of second tier cities experienced negative trends including depopulation and impoverishment of their inhabitants. As of 2017, according to the Ministry for Urban Affairs, 169 medium-sized towns (out of an identified total of 197) include one or more neighbourhoods classified under the new policy and 98 benefit from the PNRU. Outside Île-de-France, 76 old centres in small and medium-sized towns have been identified as priority neighbourhoods, half of them being new to politique de la ville.

This spatial extension of the policy raises questions. To what extent is it possible to apply a policy essentially designed for the peripheral districts of large cities to the central districts of small or mid-sized towns? In the last decades, city centres of such towns have often been the subject of local or regional policies, which aimed at residential and commercial revitalisation, while the national government was absent (Berroir et al. 2019). What are then the convergences or, on the contrary, the conflicts, between politique de la ville and these other policies?

\subsubsection{Acting for cities and towns in times of austerity}

During François Hollande's five-year term, aménagement du territoire (AT), the term dating from the 1960 s which included interventions that lacked visibility (like contrats) or sometimes failed (like coopération métropolitaine), was officially renamed égalité des territoires (literally equality of territories). This meant going back to the roots of AT, when the national government's role was to redistribute growth across the national territory. Affirming the aim of égalité des territoires (ET) half a century later was as simple a message as using the income criterion to identify urban areas in need of public action. ET is a voluntaristic term, but it is also a loose one, thus highly debatable, and may be risky if in the end the government cannot intervene in the context of a huge public deficit. However, to give credibility to the change, a Ministry for the Equality of Territories and Housing was created in 2012, and later DATAR and DIV merged to form the Commissariat Général à l'Egalité des Territoires (CGET - General Commission for Territorial Equality).

To understand this change of vocabulary, it must be said that with the further decentralisation of 2003-2004 and the various laws strengthening inter-municipal cooperation, the French cities have been entrusted with many powers which they used to share with the state after the decentralisation of the 1980s. Cities now have full responsibility for many public policies which were 
hitherto the subject of negotiations and contracts with decentralised services of state (Epstein 2016).

The French state apparatus also appears too remote from territories (and from their needs). Under Nicolas Sarkozy, there was a major reform of the territorial administration of the state, called Réforme Générale des Politiques Publiques (RGPP). Inspired by New Public Management, the objective was to reduce public spending deemed excessive, by reviewing various state policies. For the sake of efficiency and speed, the RGPP was devoted to the reorganisation of the structures of the administration and to the reduction in the number of civil servants. For example, the Ministry of Justice launched a vast plan reducing the number of courts from 1206 to 815 in a few years (2007-2011). However, the savings made by the RGPP were limited (12 billion euros, including 5 billion in staff costs). After 2012 the new socialist government ended the RGPP, public jobs were stabilised and consultation with the unions of civil servants became regular. But the government nevertheless affirmed that they wanted to continue modernising public action.

Yet by organising vast and complex mergers of decentralised services, the RGPP weakened the relations of these services with those of cities and even more with those of small towns and rural areas. Regarding urban policies, RGPP strengthened the autonomy of cities vis-à-vis the state. The national government has tried to rediscover capacities for remote control of policies developed by urban authorities. No longer having the financial resources to impose its priorities and solutions on cities, or often even the sufficient expertise to define them, the state is now making intensive use of incentive instruments supported by competitive mechanisms, to seek to influence urban agendas from a distance (Epstein 2016). An example would be the Plan Ecoquartiers (Eco-neighbourhood plan), which deals with sustainable urban development and was launched during the term of Nicolas Sarkozy. Under François Hollande, not only was this action continued, but the steering at distance was extended to other fields, like the digital economy, with the French Tech Metropole label.

France has experienced a massive reduction in the number of public services, especially outside major urban areas. Between 1980 and 2013, the number of schools declined by 24 per cent, post offices by 36 per cent, gendarmeries by 13 per cent, railway stations by 28 per cent and maternity hospitals by 48 per cent (Barczak and Hilal 2016). Small towns and the rural areas they serve have been the most impacted, further aggravating the socioeconomic problems for the population concerned.

The slogan 'égalité des territoires' is meant to be an answer to this situation, but it has resulted in only a few policy initiatives. With regard to small towns and villages, we may quote an experimental programme for the revitalisation of town centres which was launched in 2014. In official discourses, the aim 
was to consolidate the presence of 'small dynamic and lively urban centres, in the countryside as well as in peri-urban areas'. The programme took the form of a call for projects piloted by the CGET, and it mobilised 230 million euros. This programme can be critiqued for a number of reasons. First, the number of successful bids (53) is quite low compared to the 302 municipalities which had been identified by the regional prefects and invited to respond to the call for projects. Second, this experiment was intended to draw more general lessons from the actions carried out, in order to adapt the arrangements relating to public policies for the revitalisation of towns and city centres. On this point, the programme has derailed to the extent that the projects have lagged far behind schedule in the winning towns and villages. According to stakeholders, the implementation of the projects came up against cumbersome administration. In addition, in the 43 municipalities that are still involved (10 have left), fewer than 2800 dwellings were restored, in total, between 2015 and 2020. When the plan concerns the retail trade, ground floors of buildings are renovated and sometimes an online store platform is created to help the existing retailers, but attracting other retailers proves difficult in many places since many consumers tend to prefer shopping malls in peripheral areas over their city-centre counterparts.

The timidity of such 'new' national urban policy can be linked to the size of the public debt in France, which led all recent governments, whatever their political orientations, to adopt austerity. Over the past 15 years, public debt has increased significantly, from 67 per cent of GDP in 2005 to 100 per cent in 2019, while European criteria require that the public debt of member countries does not exceed the standard of 60 per cent of GDP. French governments therefore give priority to the all-round reduction of public spending. Against this background, the policies for 'égalité des territoires', in the context of disadvantaged neighbourhoods, rural areas or small towns, might seem to be only a façade, window dressing as the reorganisation of the state's territorial presence continues.

\subsection{Since 2017: Reconciling New Public Management And Territorial Cohesion?}

Since 2017 and the election of Emmanuel Macron and a new government, trends in terms of urban policy seem to follow those under Sarkozy and Hollande. As regards disadvantaged neighbourhoods, President Macron has publicly expressed his mistrust vis-à-vis big plans. The measures take aim at deepening the physical restructuring of the neighbourhoods but also the empowerment of the inhabitants through measures in the fields of education, culture and employment. Furthermore, the criticised notion of territorial equality has been replaced by territorial cohesion, at ministerial level as well 
as at that of implementation. On 1 January 2020, the CGET was replaced by an Agence nationale de la cohésion des territoires (ANCT - National Agency for the Cohesion of Territories).

The creation of the ANCT was announced by President Macron in July 2017, after associations of local elected officials had called for it. According to the Minister for Territorial Cohesion, Jacqueline Gourault, it is about 'transforming in depth the way in which the State organises its action and the support it gives to territories and their projects'. The fields of action favoured by the ANCT are access to public services, access to healthcare, mobility, mobilisation for urban areas in difficulty, revitalisation of city centres and town centres, and ecological transition. The ANCT will conduct various national territorial programmes. In addition, any interested community can sign a 'contrat de cohésion territoriale' (territorial cohesion contract) in order to be supported in achieving its development. This new contract can include all other contractualisations (contrats de ville, etc.) and promotes, in particular, cooperation with neighbouring territories.

The ANCT has a budget of 75 million euros and must operate within this amount. Its branch in charge of politique de la ville has 90 staff, which is relatively small, and the department in charge of rural areas and small and medium-sized towns has 27 staff, which is tiny. The prefect of each department becomes the territorial delegate of the ANCT. Their role is to ensure the coherence and complementarity of the agency's actions with the support provided to local projects by subnational government. There seems to be a contradiction between optimising the use of the scarce financial and human resources of the state and dealing with the territorial challenges faced by urban and rural areas.

While the big cities are not the subject of specific policies - another continuity with the actions of French governments over the past 15 years - the interest in small and medium-sized towns is reaffirmed. Thus, from 2021, a new plan should cover 800 to 1000 small towns outside large urban regions and showing signs of fragility. In addition, medium-sized towns are the subject of interventions widely promoted by the government, as emblematic of its concern for territorial cohesion. It is recognised that many such towns undergo processes of devitalisation of their centre, especially in commercial matters (CGET 2017). For example, 55 per cent of medium-sized town centres have a retail vacancy rate of more than 10 per cent, compared to only 27 per cent of large cities (IGF-CGEDD 2016). In 2018, the government launched a national programme to renovate city centres: the Action Coeur de Ville (ACV) plan. So far 222 towns have been selected to receive funding amounting to 5 billion euros. ACV certainly has the merit of putting medium-sized towns at the forefront of national urban policies. However, most of the strategies envisaged for these places stem from proactive policies which seek to prioritise a return to growth 
and development according to metropolitan models (Berroir et al. 2019). For example, actions aimed at renewing the housing supply are often presented as a priority, in order to attract new populations, especially young people or senior managers. However, these attractiveness strategies are very often out of step with the reality of shrinking towns (Berroir et al. 2019). Therefore, ACV does not seem to constitute a relevant response. This national policy should take more specific account of local conditions, rather than promoting a model that is sometimes at odds with territorial realities.

\section{ACTORS: WHO IS DRIVING THE CHANGES?}

\subsection{The Relevant Actors}

In France there have always been historic tensions between Jacobin centralising tendencies and Girondin decentralising traditions reflected in a complex and evolving state and local government architecture (Booth 2009). Power has always been more fragmented and dispersed than appears on the surface, with voluntarism from national governments regarding the development of places. There is actually a high degree of interdependence between 'local' and 'national' decision makers reflected in personal, professional and social networks between and within tiers, sometimes referred to as devolved corporatism or 'régulation croisée' (Thoenig 2005). Historically, a key factor in this regard has been the ability of powerful individuals to become elected and/ or hold senior official positions at different levels of administration, referred to as cumul des mandats. In 2012, 82 per cent of deputies of the assemblée nationale (National Assembly) and 77 per cent of senators held at least one other elected office. The proportion of parliamentarians at the head of a local executive (mayor or chairman of a département or regional council) was 45 per cent for the deputies and 48 per cent for senators. These figures make France an exception in Europe (Dolez 2015). ${ }^{3}$ For decades, the cumulation of mandates has thwarted government efforts to reform the institutional system, and especially to reduce the number of municipalities. However, in January 2014, under pressure from the national government, the French parliament adopted a law prohibiting the combination of local executive functions with a deputy's or senator's post. This law came into force on 31 March 2017. We examine below its consequences for national urban policies.

\subsubsection{Local and national politicians: the effects of the cumulation of mandates}

The widespread use of multiple mandates implied a possible confusion of roles at the top of the state. When a national government launched an urban policy initiative, the concerned ministers themselves might very well be local 
elected officials. Thus they could be both informed and influenced by the local situations, and sometimes concerned by the new scheme. To limit ourselves to the most prominent ministers in charge of la politique de la ville, like Michel Delebarre (1990-1992), Claude Bartolone (1997-2002), Jean-Louis Borloo (2002-2004), all of them were at the same time mayors or president of an EPCI. We may also add that since the beginning of the Fifth Republic, in 1958, only four Prime Ministers out of 22 had not been mayor before heading the national government.

Due to régulation croisée (joint regulation), the government always needs to find local allies to implement its policies. For instance, when decentralisation and politique de la ville were launched by socialist governments in the early 1980s, these reforms were facilitated by a very active network of left-wing mayors in many cities (Jobard 2011). With regard to policies aimed at the development of metropolises, there has been a complex set of actors between the state and certain local authorities, where it is a question of winning the collaboration of the other through confrontation and/or by negotiation. A good example is how Tours, the 20th city in France in terms of population, obtained the status of métropole in spite of the fact that its population (300000 inhabitants) is below the population threshold set by the law passed in 2014 (Demazière et al. 2020). Philippe Briand, a successful businessman, local mayor, MP and new president of the voluntary grouping of municipalities including Tours, convinced his fellow mayors that the status of métropole would place Tours on the map as a nationally significant city. He also mobilised the support of a socialist MP from the area to lobby with him in parliament. In December 2016, both MPs succeeded in tabling an amendment to the Loi du Grand Paris, a legislation dedicated to strengthening the status of this metropolis. At the committee stage of this bill the lobby group succeeded in inserting a new population threshold into the draft law to enable additional métropoles to be designated. The amendment was drafted in such a fashion that it ensured Tours uniquely fitted the journey to work and population size criteria for métropoles. The law completed its passage through the National Assembly and Senate in February 2017, resulting in Tours being designated the first additional (i.e. 16th) métropole in France.

\subsubsection{Recent success for organisations of local government officials}

Organisations of local government officials have long been weak, due to their dispersal. We counted up to 20 organisations, not established according to party affiliation but according to the size of the community (large cities, medium-sized towns, small towns, etc.) or specialisations, such as associations which, for example, bring together the mayors of the municipalities concerned by la politique de la ville, mountain areas, forest communities, rural areas and so on. Permanent interlocutors of governments and parliamentarians, the main 
organisations influencing urban policies, proactively or defensively, are the Association of Mayors of France, Urban France, and Cities of France.

Created in 1907, the Association of Mayors of France and Presidents of Inter-Municipality (AMF) promotes respect for local freedoms. It currently has more than 36000 members, mayors or presidents of EPCIs. The AMF ensures that decentralisation guarantees municipalities real autonomy in managing local affairs. To this end, it carries out significant lobbying activity with the National Assembly and governments, upstream of projects that can change the future of the municipalities.

Bringing together the mayors of cities with more than 100000 inhabitants, the Association of Mayors of Large Cities in France (AMGVF) was active from 1974 to 2015. In 2016 it merged with the Association of Urban Communities of France (ACUF) to form a new organisation: Urban France. The recent creation of métropoles, long called for by the two groups, had been an opportunity to collaborate very closely. Insofar as métropoles will develop new policies, the merger also aims to compensate for the lack of expertise of the two associations in certain fields. The introduction of non-cumulation of a parliamentary mandate and a local executive function, effective in June 2017, also argued in this direction. In fact, the AMGVF and the ACUF have lost their natural allies: deputy mayors and other senators-mayors of large cities. Now it is a question of spending more energy on parliamentary lobbying and having experts capable of proposing ready to use amendments.

Urban France brings together almost a hundred large cities and metropolises. In early 2017, it published a manifesto for candidates to the presidential election to make the voices of big cities heard. This manifesto requested the creation of a forum for dialogue between the territories and the government so that the mayors and presidents of EPCI are involved upstream in the drafting of laws which concern them. The message was heard, since, after his election, President Macron created a national conference of the territories which brings together twice a year representatives of the territorial communities and the government.

In France, associations of local elected officials are used to question candidates for the presidential election. Thus, in 2017, the AMF, Urban France and Ville et banlieue (association of mayors of municipalities where disadvantaged neighbourhoods are located) interviewed the representatives of the main candidates for the presidential election. The aim was to take stock of the various measures planned in the candidates' programmes in favour of 'politique de la ville', a subject that was little highlighted in the campaign. Similarly, the association Villes de France, which has brought together 800 medium-sized towns and their agglomerations since 1988, presented its 'appeal to candidates' for the 2017 presidential election. Villes de France advocated for the implementation of policies adapted to agglomerations of sub-metropolitan size. Through 
its lobbying with the Macron government, this association played an important role in obtaining the national Action Coeur de Ville programme.

The current government proclaims its desire for dialogue with associations of elected officials. The implementation of certain new urban policies attests that these, through their lobbying, have obtained a reorientation of national priorities, from disadvantaged urban districts to the core of small or medium-sized towns. Similarly, the creation of the ANCT had been called for by the AMF in the name of rebalancing national funding from metropolitan areas to non-metropolitan areas. This set of actors has a strong political dimension. The collapse of traditional left and right parties in the legislative elections that followed the election of Emmanuel Macron in 2017 put local elected officials back at the heart of the political game. Local and regional authorities, especially those of a large size, have become refuges for political leaders who lost the election and went into opposition. Various right-wing personalities who are preparing for the next presidential election are building their national stature through their work as local elected officials.

The Macron government had to negotiate like never before with these institutions in which it had no natural intermediary, by means of give and take. France Urbaine has achieved many advances for large cities thanks to its constructive attitude. The same strategy enabled Villes de France to obtain the revitalisation plan for medium-sized towns, while the last national programme concerning this category of cities, which was much less ambitious, dated from the mid-2000s and only affected a dozen cities, against 222 for Action Coeur de Ville.

We can see that the weakening of the big political parties has given a more partisan tone to the associations. The right-wing presidents of AMF, Regions of France and the Assembly of Departments have become important opposition voices since 2017. Constantly accusing Emmanuel Macron of recentralising the country and of weakening local elected officials, they prevented the government from carrying out a reform of local taxation.

\section{W.2 What Is the Role of the European Union?}

The perceived influence of the European Union on national urban policies remains weak for several reasons. First of all, it could be argued that Europe is not sufficiently taken into account by the national political parties (on the right as well as on the left) except when it is a question of making it a scapegoat for internal political problems (Caresche and Lequiller 2016). Second, France has had a strong influence on the first EU initiatives in the area of urban policy, more so than the reverse. As we have seen above, a national policy for the treatment of disadvantaged neighbourhoods was initiated in France in the early 1980s, at a time when EU structural funds did not target cities. In addition, 
rather than carrying out the physical treatment of neighbourhoods, politique de la ville favoured the logic of integrated urban development. Finally, the French players took care to promote their approach internationally. In the early 1990s, the DIV organised a network for exchanging experiences between ten European neighbourhoods in crisis in Belgium, France, the Netherlands and the UK (Jacquier 1991). This approach convinced the European Commission to launch the URBAN I and URBAN II community initiative programmes. The headquarters of URBACT, created to stimulate exchange between all the European cities interested in developing integrated urban policies, is still based in Saint Denis (Paris) and the director is French.

If the European Union has had an influence, it is probably in relation to the mode of governance of urban projects. At the local level, the use of URBAN, cross-border programmes or structural funds has instituted conditions of partnership, co-financing, and evaluation which have become standards of governance. This has forged among local elected representatives a knowledge of European mechanisms, and contributed to the practice of evaluation and to international openness. Sometimes, elected officials see only lines of credit and downplay the importance of the dissemination of practices and the resulting improvement in skills. But in times of constrained budgets, as is the case in France today, the financial contribution is very appreciated.

The European Union also insists on subsidiarity: a project must be that of a territory, with funding from local authorities allowing the contributions of the Union. In this sense, after long resistance from national governments, the regions are now in charge of managing European structural funds. On the other hand, for politique de la ville, the integrated approach targeted at deprived neighbourhoods is fixed as a priority in the Partnership Agreement between the European Commission and France, specifying that at least 10 per cent of the national allocation from the European Regional Development Fund (ERDF) and the European Social Fund (ESF) needs to support integrated urban strategies. As a result, the national government incorporates such funds into city contracts, which involve all levels of subnational government, including the regions which manage the structural funds. Concerning the usability of European Structural and Investment (ESI) Funds for urban development, there is room for improvement in the complementarity of the place-based (ERDF) and people-based (ESF) logic of funds. Topics like urban poverty, which require combined efforts, could be targeted more effectively with better integrated funding possibilities.

The enlargements of the European Union to Central Europe have greatly reduced the eligibility of French cities, and due to Brexit the next funding period will offer even less ERDF and ESF money for French cities. It is on this policy that France records its lowest rate of return relative to its contributions (Caresche and Lequiller 2016). 


\subsection{Do Parties Matter?}

Cole (2008) argues that in France the main parties from the left or from the right remain strongly attached to the French social values inherent in the social welfare model and citizenship. While in the UK the Conservative Party has shrunk the social housing sector, all the main French parties continue to support the principle of social housing and of providing social and support services for poorer fellow citizens (Laffin 2019). However, this is more true of the Socialists than the right - indeed, during the years 1980 to 1990, there was a will in the Socialist Party to regenerate the banlieues, with the objective of mobilising the popular electorate for its benefit during local and national elections (thus favouring the retreat of the Communist Party). For his part, the leader of the right party in the 2000s, Nicolas Sarkozy, made shocking remarks about the supposed insecurity of these same districts and his will to restore French identity. During the 2007 presidential campaign, this allowed him to significantly siphon the electorate from the far right. In the presidential elections of 2012 and 2017, the far right achieved its best scores in small towns and rural areas. This explains the subsequent emphasis on 'territorial equality' or 'territorial cohesion', as well as the regeneration schemes for medium-sized and small towns. However, French political parties do not explicitly refer to urban policy in their programmes. As Sykes and Desjardins (2017, p. 322) note, for example, 'The French presidential campaign of spring 2017 was not marked by a strong emphasis on "the city", or urban futures.'

\section{CONCLUSIONS}

The story of the evolution of national urban policy in France is multifaceted and distinctive while also reflecting more universal trends around how cities and the urban dimension are addressed by the state in the context of changing spatial dynamics and governance patterns.

As regards the system of sub-state government, a key question has long been, and remains, how the administrative geography captures and responds to the opportunities and challenges of 'urban France'. The country is characterised by the fragmentation of municipalities within the context of a state which has become progressively more decentralised since the 1980s. This has led to successive attempts to develop 'critical' mass to address the issues of urban areas through the promotion of intercommunal structures and, most recently in the 2010s, to major territorial reform which has redefined the levels of subnational government and their competences - notably with the creation of métropoles.

The locus of 'urban challenges', and the resultant focus of urban policy, has evolved over time. The 1970s and 1980s saw the emergence of a politique de 
la ville alongside the established French version of national regional/spatial policy - aménagement du territoire. Thus 'national urban policy' within France has two principal foci: policies that seek to address conurbations and urban areas as a whole (sometimes within a national perspective), and policies which address deprived neighbourhoods within cities. The emphasis of policy has shifted over time, often in reaction to the recognition of novel urban challenges. In the 2010s, the challenges of smaller and medium-sized urban places came to the fore as the economic and demographic trends leading to their decline increasingly came to be seen as a major challenge to territorial cohesion. Meanwhile, the economic and demographic dynamism of large French cities, and reforms designed to meet their needs such as the creation of métropoles, nurtured the notion of a territorial divide between metropolises and neglected peripheral areas. This underlines another theme with more universal resonance: the extent to which an urban policy seeks to promote and balance the economic competitiveness of the 'national' urban system and individual conurbations, and/or address issues of spatial disadvantage and nurture territorial cohesion. Mirroring trends in other countries, the respective emphasis of urban policy in France on these goals has varied over time.

Another theme which emerges above, again which resonates with wider debates on urban policy, is the extent to which challenges facing urban areas are seen as ultimately resolvable through 'grand plans' and vast investments, with a noticeable cooling in the past two decades of faith in these as being able to provide an ultimate 'fix' to enduring issues such as the 'crisis of the suburbs'. Despite this, the shift in terminology back to égalité des territoires over the past decade, for example, reaffirms the roots of urban policy in notions of republican equality. Similarly, over the same period small and medium-sized towns have been accepted as a new category of urban areas meriting a renewed national policy response. There is an urgent political imperative here: in the presidential elections of 2012 and 2017, the far right achieved its best scores in small towns and rural areas. However, the capacity of the state to intervene is inevitably constrained by mounting public debt. Furthermore, under the impulsion of decentralisation and managerialist and efficiency-seeking reforms, the spatial 'density' of the French state apparatus across certain of these kinds of territories has diminished. For these reasons, the picture today is one of evolution not revolution in French urban policy, with a continuation of the key trends of the past decade.

\section{NOTES}

1. Of the Prime Ministers of the last half century, six were mayors of a very large French city, often for long periods: Bordeaux (1947-1995, 1995-2019), 
Lille (1973-2001), Lyon (1995-2001), Nantes (1989-2012), Paris (1977-1995). Holding a mayor's mandate has often been a must for a national political career.

2. Since then, 14 more métropoles have been created, reaching a total number of 22 in 2017. While Greater Paris has over 7 million inhabitants, the smallest métropoles have fewer than 250000 .

3. In Italy, 16 per cent of parliamentarians hold at least one other elected office, 15 per cent in Spain, 13 per cent in Great Britain and 10 per cent in Germany (Dolez 2015).

\section{REFERENCES}

Barczak, A. and M. Hilal (2016), 'Quelle évolution de la présence des services publics en France?', in T. Courcelle, Y. Fijalkow and F. Taulelle (eds), Aménagement du territoire et services publics, Rennes: Presses Universitaires de Rennes, pp. 43-58.

Berroir, S., S. Fol, C. Quéva and F. Santamaria (2019), 'Villes moyennes et dévitalisation des centres: les politiques publiques face aux enjeux d'égalité territoriale', Belgeo. Revue belge de géographie, (3), https://doi.org/10.4000/belgeo.33736.

Booth, P. (2009), 'Planning and the culture of governance: local institutions and reform in France', European Planning Studies, 26 (5), 677-695.

Caresche, C. and P. Lequiller (2016), Rapport d'information déposé par la Commission des Affaires Européennes sur l'influence française au sein de l'Union européenne, Paris: Assemblée nationale, 2 février 2016.

Cole, A. (2008), Governing and Governance in France, Cambridge: Cambridge University Press.

Commissariat Général à l'Egalité des Territoires (CGET) (2017), Regards croisés sur les villes moyennes, Paris: La Documentation française.

Couch, C., O. Sykes and B. Borstinghaus (2011), 'Thirty years of urban regeneration in Britain, Germany and France: the importance of context and path dependency', Progress in Planning, 75 (1), 1-52.

Demazière, C. (2006), 'L'Etat et les acteurs locaux dans la mise en place des pôles de compétitivité en France', Annales de la Recherche Urbaine, (101), 33-39.

Demazière, C. (2017), 'The place of small and medium-sized towns in urban studies', Espaces et sociétés, 168-169 (1), 17-32.

Demazière, C., S. Hall and J. Mawson (2020), 'Les métropoles françaises vues d'Angleterre: un jeu entre l'Etat et les notables?', in C. Demazière, O. Sykes and X. Desjardins (eds), La gouvernance des métropoles. Des réformes institutionnelles aux coopérations territoriales, Paris: PUCA, pp. 43-63.

Demazière, C. and O. Sykes (2020), 'Metropolitan development and governance: the cases of England and France', in S. Armondi and S. Di Gregorio Hurtado (eds), Foregrounding Urban Agendas, Berlin: Springer, pp. 185-209.

Dolez, B. (2015), 'Le cumul des mandats, la professionnalisation des élus et la réforme territoriale', Revue française d'administration publique, 156 (4), 931-944.

Donzelot, J. (2003), Faire société: La Politique de la ville aux Etats-Unis et en France, Paris: Seuil.

Epstein, R. (2015), 'La gouvernance territoriale: une affaire d'Etat. La dimension verticale de la construction de l'action collective dans les territoires', L'Année sociologique, 65 (2), 457-482. 
Epstein, R. (2016), 'Le “problème des banlieues" après la désillusion de la rénovation', Métropolitiques, accessed 6 August 2020 at https://www.metropolitiques.eu/Le -probleme-des-banlieues-apres-la.html.

Guilluy, C. (2014), La France périphérique: Comment on a sacrifié les classes populaires, Paris: Flammarion.

Hall, S. and P. Hickman (2002), 'Neighbourhood renewal and urban policy: a comparison of new approaches in England and France', Regional Studies, 36 (6), 691-707.

IGF-CGEDD (2016), La revitalisation commerciale des centres-villes, Rapport pour l'Inspection Générale des Finances et le Conseil Général de l'Environnement et du Développement Durable, Paris: CGEDD.

Jacquier, C. (1991), Voyage dans dix quartiers européens en crise, Paris: L'Harmattan. Jessop, B. (1993), 'Toward a Schumpeterian welfare state? Preliminary remarks on post-Fordist political economy', Studies in Political Economy, 40 (1), 7-39.

Jobard, F. (2011), 'An overview of the French riots, 1981-2004', in F. Waddington, F. Jobard and M. King (eds), Rioting in the UK and France: A Comparative Analysis, London: Routledge, pp. 27-39.

Laffin, M. (2019), 'Explaining reforms - post-New Public Management myths or political realities? Social housing delivery in England and France', International Review of Administrative Sciences, 85 (1), 45-61.

Lelévrier, C. (1999), 'Renaissance ou fin de la politique de la ville?', Cahiers de l'IAU$R I F,(123), 9-34$.

Lévy-Vroelant, C. (2007), 'Urban renewal in France - what or who is at stake?', Innovation: The European Journal of Social Science Research, 20 (2), 109-118.

Observatoire des territoires (2017), Regards sur les territoires. Rapport de l'Observatoire des territoires 2017, Paris: CGET.

Rozenblat, C. and P. Cicille (2003), Les villes européennes: analyse comparative, Paris: DIACT.

Sueur, J.-P. (1998), Demain la ville, Paris: La Documentation Française.

Sykes, O. and X. Desjardins (2017), 'Another country', Town and Country Planning, August, 322-328.

Thoenig, J.-C. (2005), 'Territorial administration and political control: decentralisation in France', Public Administration, 83 (3), 685-708.

Tickell, A. and J. Peck (2003), 'Making global rules: globalisation or neoliberalisation', in J. Peck and H. Yeung (eds), Remaking the Global Economy, London: Sage, pp. $163-182$.

Vanier, M. (2007), 'Grenoble: une technopole en quête d'horizon métropolitain', in A. Motte (ed.), Les agglomérations françaises face aux défis métropolitains, Paris: Economica, pp. 62-79. 